\title{
Observations on 205 confirmed cases of acute pancreatitis, recurring pancreatitis, and chronic pancreatitis
}

\author{
HENRI SARLES, JEAN-CLAUDE SARLES, ROGER CAMATTE, RAYMOND \\ MURATORE, MICHEL GAINI, CLAUDE GUIEN, JEAN PASTOR, AND \\ FRANÇOISE LE ROY \\ From Unité de Recherches de Pathologie digestive de l'Institut National \\ de la Santé et de la Recherche médicale, Hôpital Sainte-Marguerite, Marseilles
}

EDITORIAL SYNOPSIS Two hundred and five confirmed cases of pancreatitis have been classified. Primary calcifying pancreatitis is associated with alcoholism. Pancreatic changes are patchy and related to plugging of minute ducts. Cysts are frequent. Obstruction to the main pancreatic duct may also result in chronic pancreatitis. Acute pancreatitis and acute recurrent pancreatitis are often associated with gall stones. Acute pancreatitis rarely progresses towards the chronic form.

Since Comfort, Gambill, and Baggenstoss (1946) and Gambill, Comfort, and Baggenstoss (1948) described the natural history of chronic relapsing pancreatitis there has been a general tendency to group all forms of pancreatitis, from acute haemorrhagic pancreatitis to calcifying pancreatitis, as features of the same progressive disease. Sarles, Muratore, and Sarles (1961), however, consider that acute pancreatitis has a different aetiology from chronic pancreatitis, citing that acute pancreatitis begins at a more advanced age than chronic pancreatitis and that while gall stones are more frequently found in the former condition, alcoholism is more prevalent in the latter.

According to Marks and Bank (1963), the conventional classification into acute, relapsing, and chronic types has minimized the importance of an aetiological approach and led to a standard medical and surgical attack on the disease irrespective of the specific cause in the individual patient. Little attempt is often made to identify and eradicate the causal factors in these patients. More recently Fitzgerald, Fennelly, McMullin, and Boland (1963) have criticised the term 'chronic relapsing pancreatitis' and proposed in its place that of 'chronic progressive pancreatitis'.

The term 'acute pancreatitis', recurrent pancreatitis, and 'chronic pancreatitis' are employed with different meanings by different writers. During a symposium held in Marseilles in April 1963 (1965) to discuss the clinical and pathological features of chronic pancreatitis, clinicians and pathologists from seven European countries met and adopted unanimously a classification for pancreatitis which has been used in this paper.

ACUTE PANCREATITIS AND RELAPSING ACUTE PANCREATITIS In these two acute forms the pancreas is restored to normal clinically and functionally when the initial cause or factors leading to the illness are eliminated.

CHRONIC PANCREATITIS AND RELAPSING CHRONIC PANCREATITIS By this is meant chronic pancreatitis with acute exacerbations. In these two chronic forms anatomical and functional changes persist in the pancreas even if the initial cause and factors leading to the disease are eliminated. The distinction between the two groups, relapsing chronic pancreatitis and chronic pancreatitis, is essentially clinical and not anatomical.

The purpose of this paper is to establish a correlation between the histological aspects of pancreatitis on the one hand and on the other the causes and natural history of pancreatitis.

\section{GROUPING OF CASES}

All the patients were studied in Marseilles hospitals. Of a total of rather more than 500 painful abdominal syndromes, not due to malignancy but associated with functional insufficiency of the pancreas, the following groups were selected.

1 CHRONIC PANCREATITIS WITH RADIOLOGICAL EVIDENCE OF CALCIFICATION One hundred patients presented with 
radiological calcification indisputably of pancreatic origin, and in 47 of these the pancreas was examined histologically.

2 CHRONIC PANCREATITIS WITHOUT RADIOLOGICAL EVIDENCE OF CALCIFICATION Only patients who had been operated on and who had had a pancreatic biopsy revealing chronic pancreatic lesions of fibrosis of the organ and diminution of the exocrine parenchyma were retained and numbered 15 .

3 ACUTE PANCREATITIS There were 91 patients, operated on intentionally or in error, in whom were present the lesions of acute pancreatitis-oedematous, necrotic, or haemorrhagic. One of these patients has evolved towards a chronic pancreatitis, and she has been finally placed in that group. Fourteen others have had recurring acute attacks, then have been finally cured; these are patients with relapsing acute pancreatitis.

These very strict diagnostic criteriea have led to the elimination of more than half of our observations and hence exaggerated the relative frequency of calcifying pancreatitis. However, the result is a group of cases of pancreatitis in which the diagnosis was indisputable.

TESTS

In addition to a careful history and a clinical examination the patients with acute pancreatitis had one or more estimations of serum amylase and repeated estimations of blood sugar. Patients with chronic pancreatitis were investigated by duodenal intubation, earlier cases with the simple estimation of duodenal lipase, later cases by the technique of Burton, Evans, Harper, Howat, Oleesky, Scott, and Varley (1960) using secretin (Vitrum) and pancreozymin (Boots or Vitrum). In more than half of the cases fat balance studies were performed over a period of three days. An estimation of amino-acids in urine and the serum by two-dimensional paper chromatography was performed in five patients who had calcifying pancreatitis.

A sweat test was carried out according to the technique of Hennequet, Debris, and Marie (1958) in 42 patients. For each patient there was also carried out at the same hour of the day at the same time of the year a test on the sweat of a control subject within two years of the patient's age, and of the same sex who was free of pulmonary disease, diabetes, and gastro-duodenal ulcer.

Seventy-seven patients were interrogated about their dietary intake, if possible in the presence of their family, by a dietitian trained specially for the work, who, applying the tables of Tremolieres, Serville, and Jacquot (1956), calculated the mean dietary and alcohol intake of these patients. On the same day the same dietitian also interrogated two normal subjects within two years of age and of the same sex and of comparable profession and of the same racial origin to act as controls.

A laparotomy was undertaken on 76 patients with chronic pancreatitis (Lamy, Sarles, and Bricot, 1963; Sarles and Mercadier, 1960). During operation cholangiography was performed and at least six radiographs taken. During operations pancreatography of the canal of
Wirsung, either by direct puncture or after excision of the tail of the pancreas or more rarely after duodenotomy, necessitated taking from four to eight additional films, using image intensification and transmitted by closed circuit television in the operating theatre. In no case has any ill result been observed following the instillation of $35 \%$ diodone into the pancreatic duct. In five patients splenoportography was carried out by transplenic puncture a few days before operation and in seven cases lymphangiography was performed.

\section{RESULTS}

PRIMARY CALCIFYING PANCREATITIS Into this group fall patients (100 cases; 93 men, seven women) who presented with calcification in the duct of Wirsung either in the larger branches or in the finer peripheral ducts, with the exception of one patient classified as a pancreatitis secondary to cancer.

Aetiology The mean age (Fig. 1) at the first painful crisis in the 93 patients who presented with pain was 38.4 years (S.D. $=18$, range 22 to 67 ). Fifty-five patients were interrogated about their eating habits (Table I). Only one patient was a total abstainer and only five were accustomed to drinking

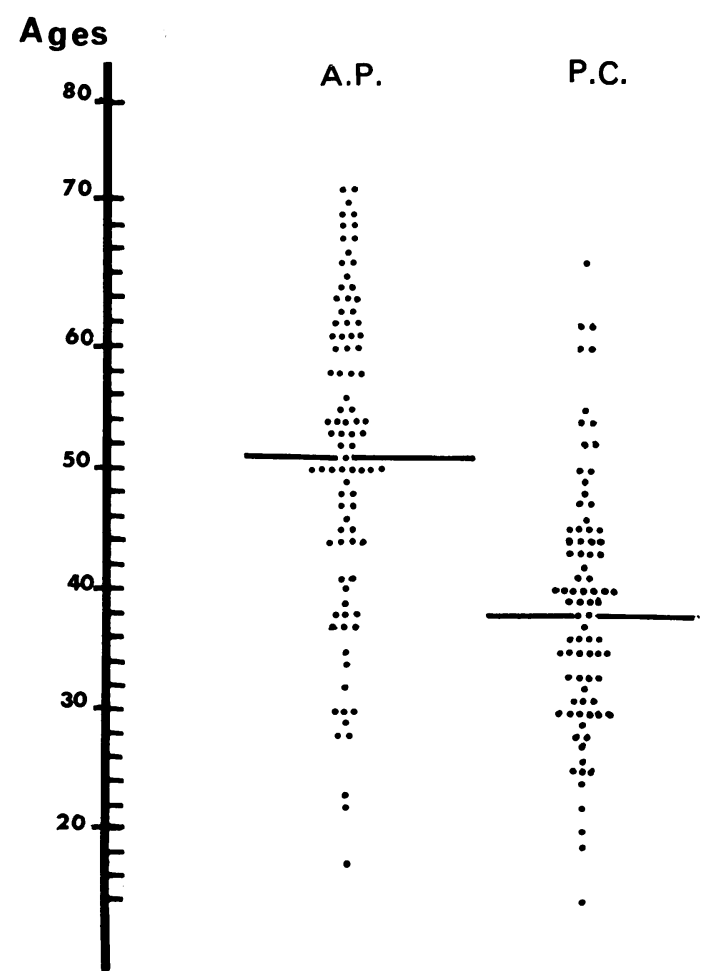

FIG. 1. The age distribution at which the acute episode of haemorrhagic or oedematous pancreatitis (A.P.) and the first attack of chronic calcifying pancreatitis (P.C.) took place. 
Observations on 205 confirmed cases of acute pancreatitis, recurring pancreatitis, and chronic pancreatitis 547

TABLE I

DIETARY INTAKE OF 55 PATIENTS WITH PRIMARY CALCIFYING PANCREATITIS AND TWO CONTROL GROUPS

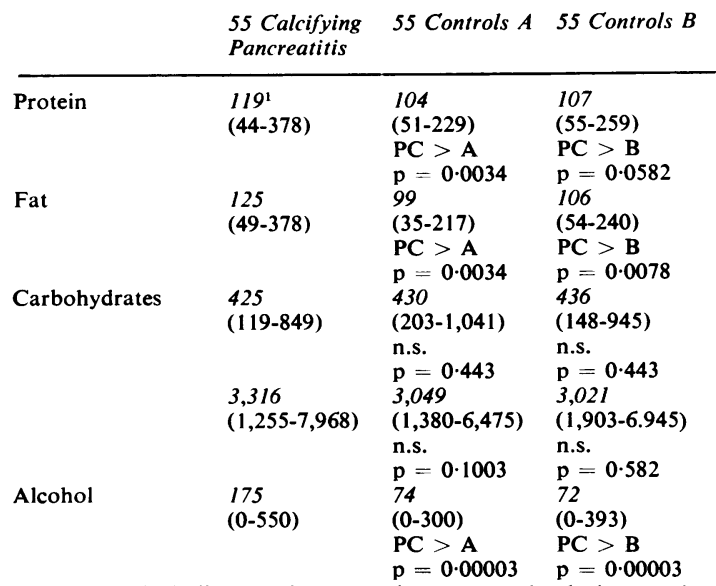

${ }^{1}$ The values in italics are the means in grams and calories per day; the values in parenthesis are the range. Significance is calculated by the sign test.

less than $50 \mathrm{~g}$. of alcohol a day. A gall bladder stone was found in two cases. Two cases came from the same family, an uncle and nephew. In the younger of these two patients we were unable to find abnormal aminoaciduria.

Clinical features These are presented in Table II. A sweat test was carried out in $\mathbf{4 2}$ patients and in a number of identical and comparable controls (Table III).
TABLE III

SWEAT TESTS IN PATIENTS WITH CALCIFYING PANCREATITIS AND IN CONTROLS

$\begin{array}{lll}\begin{array}{l}\text { Sodium } \\ \text { Chloride }\end{array} & \begin{array}{l}\text { Sodium } \\ \text { (38 cases) }\end{array} & \begin{array}{l}\text { Potassium } \\ \text { (38 cases) }\end{array}\end{array}$

\begin{tabular}{llll}
\hline Calcifying & $m=56$ & $m=69$ & $m=7$ \\
pancreatitis & S.D. $=23.49$ & S. $D .=24.10$ & S. $D=1.6$ \\
Controls & $m=42$ & $m=51$ & $m=8$ \\
& S.D. $=11.95$ & S. $D=16$ & S. $D=2.33$ \\
Probability & for PC $>$ C & for PC $>C$ & for C $>$ PC \\
& $p=0.0007$ & $p=0.0007$ & $p=0.0594$
\end{tabular}

Significance is calculated by the sign test.

Histology A histological study was carried out in 47 patients: once on necropsy material, 17 times on larger sections obtained at partial pancreatectomy, and 29 times on biopsy specimens taken during operation (Table IV). A characteristic feature of the anatomical lesions, at least at the onset of the disease, was the irregularity of their distribution. One of our patients presented a normal pancreas with the exception of a small area, about $1.5 \mathrm{~cm}$. in diameter, in which there was intense sclerosis with a diminution of exocrine parenchyma and a dilatation of the ducts which contained calculi. This pathological area related to the duct of Santorini which dilated, the duct of Wirsung being normal.

In the later stages the lesions were diffuse but the severity varied from one area to another (Fig. 2). The juxtaposition of normal and pathological areas was seen only in those cases in which the duct of Wirsung remained normal. As soon as it dilated lesions were found diffusely throughout the gland

T A B LE I I

CLINICAL FEATURES OF 100 PATIENTS WITH PRIMARY CALCIFYING PANCREATITIS

Clinical Feature

No. of Cases

Pain

Present

Absent

Recurrent (lasting from two hours to 10 days separated by intervals of

8 days to 35 years)

Daily

Sited in the mid epigastrium

Sited in the back

Sited in the right hypochondrium

Sited in the left hypochondrium

Partially relieved by bending forward

Loss of weight

Jaundice

Portal hypertension

Complications

Carbohydrate metabolism (studied in 78 cases)

Fat balance (performed in 48 patients)
In 34 patients following the painful crises, lasting from two to eight days in 33 , or more than one month in three

Haematemesis

Melaena

Pulmonary tuberculosis

Addiction to morphine

Arteritis of the lower limbs

Alcoholic cirrhosis of the liver

Pulmonary abscess

Gout cured after pancreatico-jejunal anastomosis

True diabetes

Diminution of glucose tolerance

Normal glucose tolerance

Hypoglycaemia without any suggestive clinical symptoms

Steatorrhoea from $5 \cdot 5$ to 50 g. per day over three-day period 


\section{TABLE IV}

\section{HISTOLOGY}

\begin{tabular}{|c|c|c|c|}
\hline & & $\begin{array}{l}\text { Primary } \\
\text { Calcifying } \\
\text { Pancreatitis } \\
(47 \text { cases })\end{array}$ & $\begin{array}{l}\text { Primary } \\
\text { Inflammatory } \\
\text { Pancreatitis } \\
(4 \text { cases) }\end{array}$ \\
\hline \multirow[t]{7}{*}{ Sclerosis } & 0 & 2 & 0 \\
\hline & + & 4 & \\
\hline & ++ & 18 & \\
\hline & $+t+$ & 23 & 4 \\
\hline & Diffuse & 9 & 4 \\
\hline & Intralobular & 31 & 4 \\
\hline & Perilobular & 37 & 4 \\
\hline \multirow[t]{2}{*}{ Sclerolipomatosis } & $0-4$ & 41 & 4 \\
\hline & ++ & 6 & \\
\hline \multirow{2}{*}{ Inflammation } & $0-+$ & 38 & \\
\hline & ++ & 9 & 4 \\
\hline \multirow[t]{2}{*}{$\begin{array}{l}\text { Exocrine } \\
\text { parenchyma }\end{array}$} & $\begin{array}{l}\text { Absent or } \\
\text { poor }\end{array}$ & 22 & 4 \\
\hline & $\begin{array}{l}\text { Little or no } \\
\text { reduction }\end{array}$ & 25 & \\
\hline \multirow{4}{*}{$\begin{array}{l}\text { Islets of } \\
\text { Langerhans }\end{array}$} & Normal & & 4 \\
\hline & Diminished & 17 & \\
\hline & Increased & 14 & \\
\hline & $\begin{array}{l}\text { Discrete } \\
\text { islets }\end{array}$ & 16 & \\
\hline \multirow{4}{*}{$\begin{array}{l}\text { Canalicular } \\
\text { dedifferentiation } \\
\text { of the acini }\end{array}$} & 0 & 8 & 4 \\
\hline & + & 5 & \\
\hline & ++ & 21 & \\
\hline & +++ & 13 & \\
\hline \multirow[t]{4}{*}{ Ductules } & $\begin{array}{l}\text { Absent on } \\
\text { section }\end{array}$ & 9 & \\
\hline & Normal & 3 & 4 \\
\hline & Dilated & 35 & \\
\hline & Mucous plugs & 18 & \\
\hline \multirow[t]{5}{*}{ Larger ducts } & $\begin{array}{l}\text { Absent on } \\
\text { section }\end{array}$ & 16 & \\
\hline & Normal & 5 & 3 \\
\hline & Dilated & 18 & 1 \\
\hline & $\begin{array}{l}\text { Cavities with- } \\
\text { out continuous } \\
\text { lining }\end{array}$ & 9 & \\
\hline & $\begin{array}{l}\text { IIning } \\
\text { Plugs }\end{array}$ & 16 & \\
\hline
\end{tabular}

distal to the obstruction. The localization of focal lesions appeared to correspond to the areas supplied by the ducts of variable calibre.

Sclerosis was absent in two cases only and present in 45 cases, in eight associated with sclerolipomatosis. Inflammation was absent or insignificant (small areas of lymphocytic infiltration) in 38 cases. It was marked by an increased number of inflammatory cells in nine cases.

Pancreatic and peripancreatic oedema can be seen when a laparotomy is done during or shortly after a crisis, especially when the pancreas is less severely affected. During a painful crisis oedema may compress the common duct in its intrapancreatic course and lead to icterus. Even when the exocrine parenchyma is much destroyed it is remarkable to be able to identify normal acini and see an almost intact lobule in juxtaposition to very marked sclerosis. The most frequent and characteristic feature is 'canalicular dedifferentiation of the acini' flattening of the epithelial cells surrounding the central lumen which is more or less dilated. This

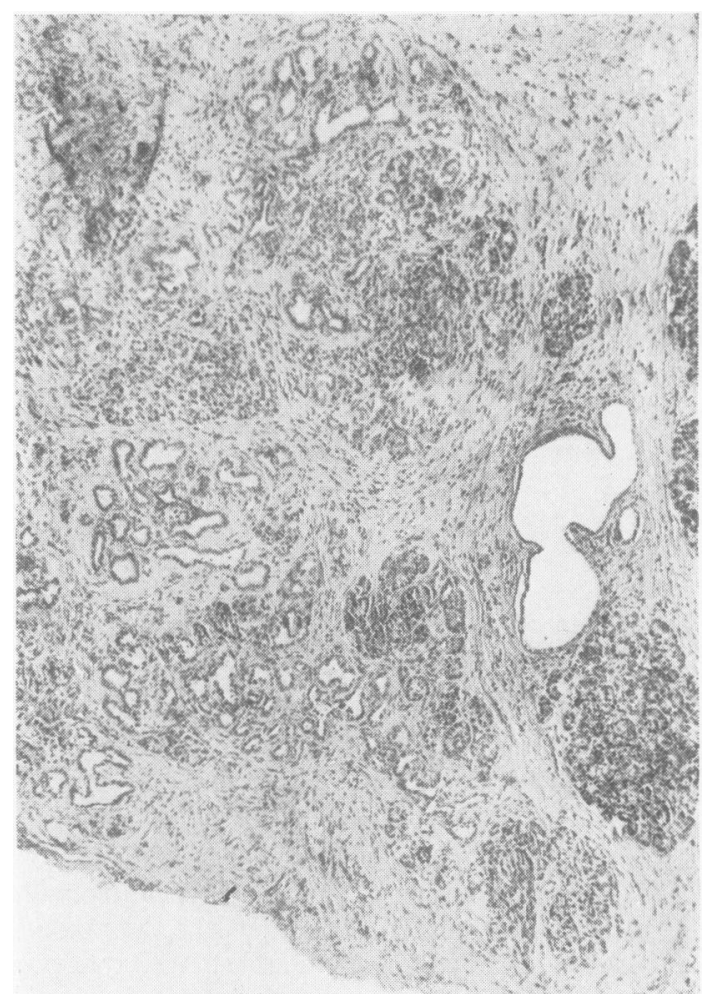

FIG. 2. In calcifying pancreatitis, the lesions vary very much from one lobule to the next. Some lobules are almost intact; others show complete canalicular dedifferentiation and canalicular dilatation; sclerosis.

appearance was observed in 39 but was absent in eight cases (Fig. 2).

The endocrine parenchyma varies tremendously. It was reduced or absent in 17 cases and apparently increased in 14 cases (Fig. 3). In 16 cases only isolated islets were present. We have not been able to correlate the presence of endocrine tissue with disturbance of glucose metabolism.

Some small ducts were well seen on biopsy in 38 cases, in only three of which were these normal. In 35 cases they were dilated, the epithelium often having features of mucinous cells. In 18 cases the small ducts contained a substance either amorphous or disposed concentrically with some epithelial debris (Fig. 4). Topographically these plugs were frequently found in small ductules but might be observed in the acini. The large ducts were seen in 32 cases. In three they were normal and in 18 they were dilated. In nine cases we saw cavities without continuous walls in the pancreatic tissue with in places epithelial debris attached to the wall. These cavities appear to be dilated ducts lined with very largely altered epithelium. Abnormal precipitates 


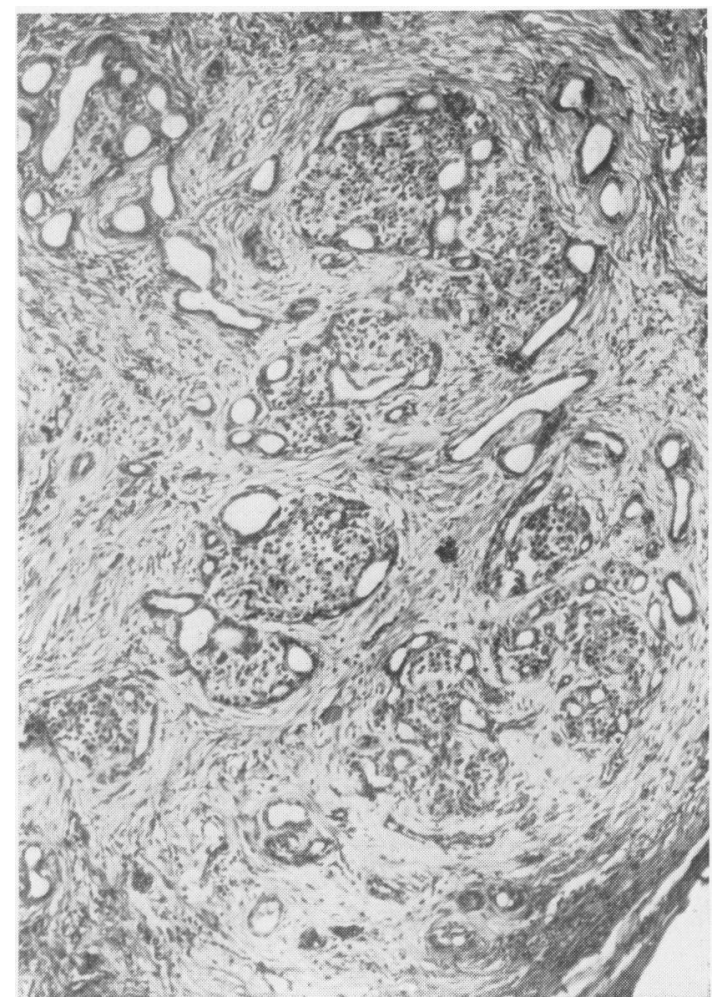

FIG. 3. Calcifying pancreatitis showing very numerous islets of Langerhans; a transitional appearance between these and the dilated acini.

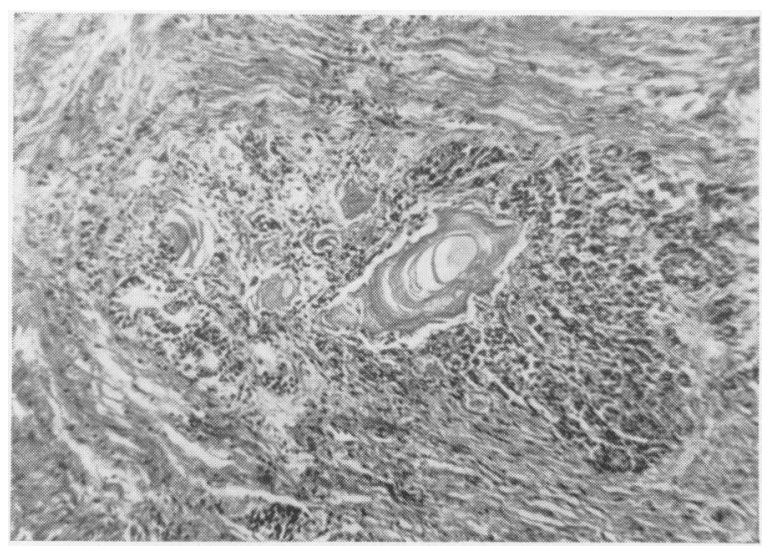

FIG. 4. Calcifying pancreatitis showing a tiny mucoprotein plug in a canaliculus. Small plugs in dilated acini adjoining it. were noted 16 times in the larger ducts. Rarely they present the appearances of massive calcification. The epithelium can be absolutely normal. It can also be changed with mucoid degeneration or with zones of epidermal metaplasia or more or less complete desquamation. No correlation exists between the dilatation of the peripheral ducts and that of the duct of Wirsung. In two cases in which the duct of Wirsung was normal on pancreatography there existed foci of acino-canalicular dilatation. Nor does there exist a correlation between the level of excretion of sodium chloride in the sweat and the type of the histological lesion.

The calcified precipitates can be slight, in the smaller peripheral ducts or in the larger ones, forming calculi in the duct of Wirsung (Fig. 5) or one of its dilated branches. Stones were always present in the ducts. The peripheral localization of calcification is often associated with calculi of the duct of Wirsung. We never saw a primary lithiasis of the duct of Wirsung. In five cases calcification appeared one to three years after anatomical examination had revealed acino-canalicular dilatation and foci of sclerosis.

In a single case we found a cancer of the pancreas associated with a diffuse calcifying pancreatitis of long standing, and we have classified in the section of pancreatitis secondary to an obstruction a second case of cancer of the pancreas associated with calcification.

Pancreatography In 55 pancreatographies the duct of Wirsung was normal on 13 occasions and dilated in 42 cases, always due to obstruction which was twice as often a stenosis (Figs. 6 and 7) as a collection of stones (Fig. 8). The narrowed segment lies generally in the region of the head, more often in the isthmus, and sometimes it is multiple (two strictures). Stenosis of the duct of Wirsung is not the initial cause of the disease for it is absent when histological lesions are still localized to restricted areas surrounded by normal tissue. When stenosis exists the intraductal pressure is always raised at operation.

Pancreatography reveals frequent cyst formation. In 53 cases explored at operation 26 patients had pseudo-cysts. On 11 occasions there were extrapancreatic cysts of considerable size (Fig. 10), four of which were suppurating. In 16 cases there were small intrapancreatic cysts varying from 1 to $4 \mathrm{~cm}$. in diameter (Figs. 6 and 9). The cysts may be single or multiple and can communicate with the pancreatic duct or be detached from it. Three of our patients had a large extrapancreatic pseudo-cyst at the onset, the rest of the pancreas being apparently normal at this time, but two or three years later these patients had developed calcifying pancreatitis. In 17 of 80 


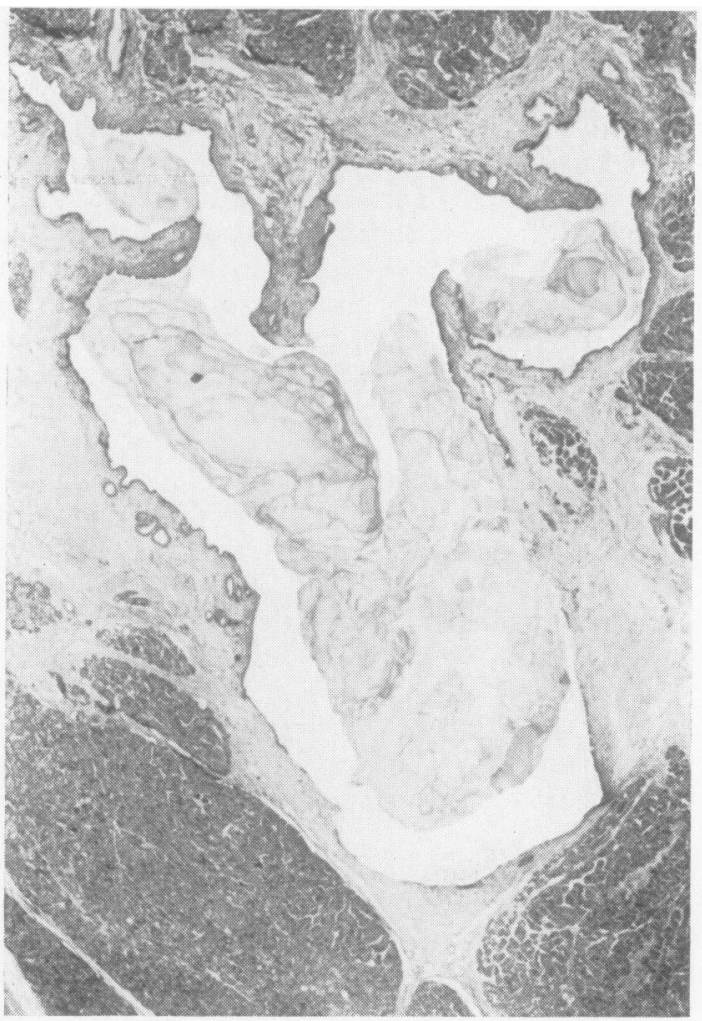

FIGS. 5a and b. Calcifying pancreatitis: grossly dilated duct containing a mucoprotein plug. The epithelium is little changed.

FIG. 5a

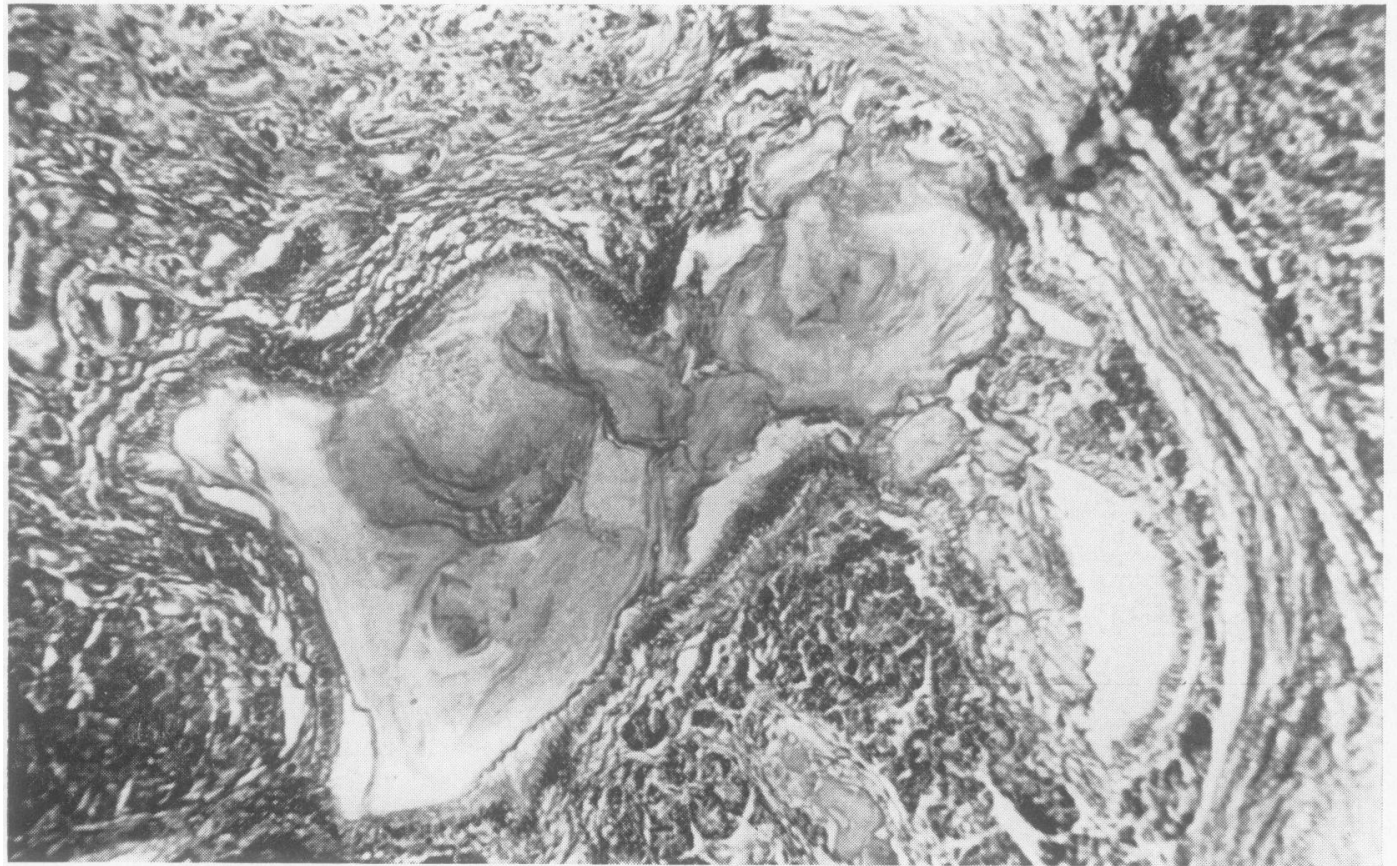




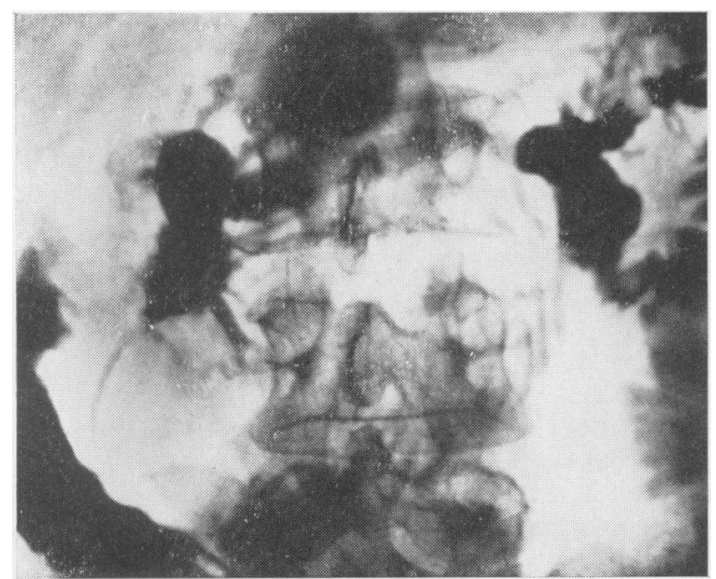

FIG. 6. Calcifying pancreatitis: pancreatography during operation by direct puncture of the duct of Wirsung. A cyst which does not communicate with the duct has been independently outlined by injection. The duct is seen above it in the region of the spine. The duodenum has been outlined at a perfusion pressure of $50 \mathrm{~cm}$. of water. The duct of Wirsung is dilated. A very narrow stricture is present in the terminal part of the duct.

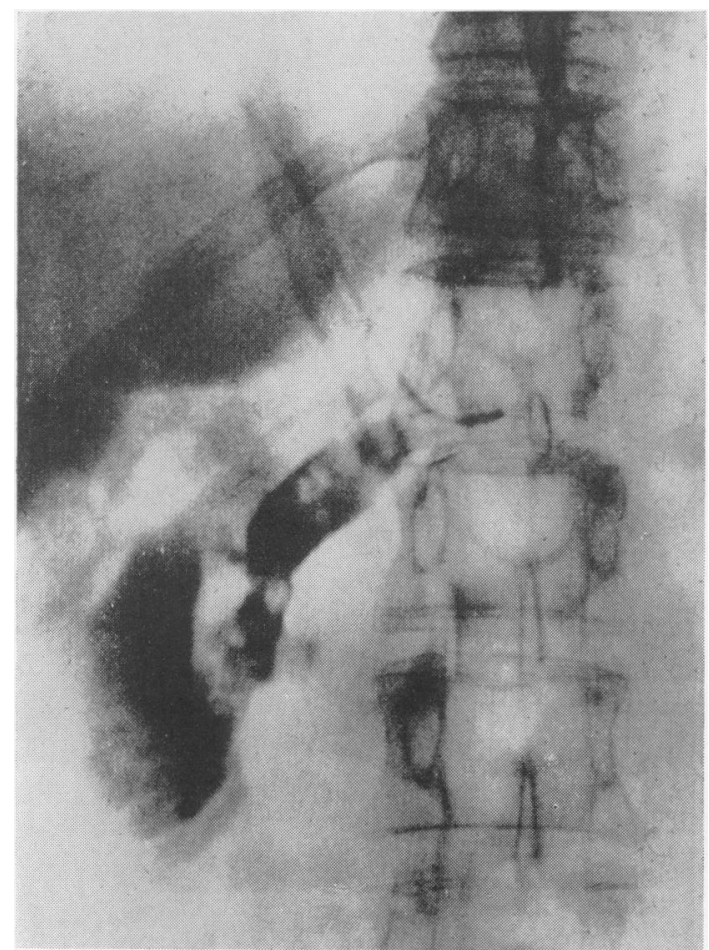

FIG. 8. Calcifying pancreatitis: pancreatography by direct puncture of the duct during operation. Dilated duct, obstruction being caused by a collection of easily seen pancreatic calculi. The duodenum was filled at a pressure of $25 \mathrm{~cm}$. of water.

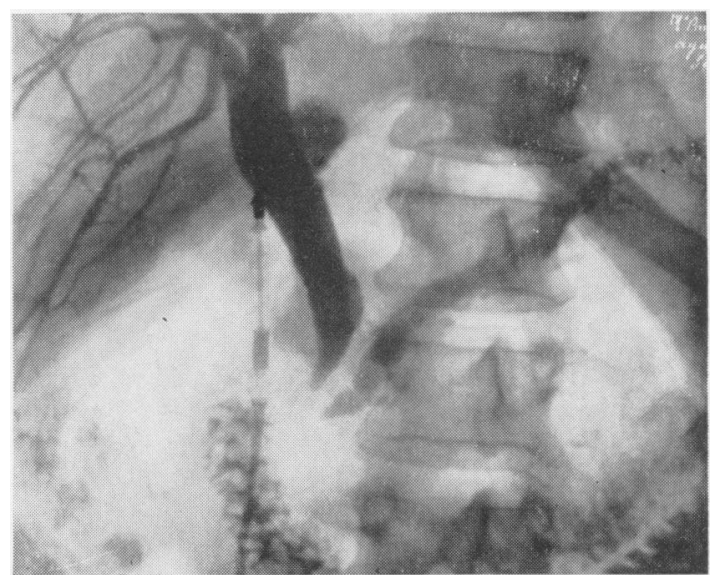

FI3. 7. Calcifying pancreatitis: cholangiography and pancreatography during operation by direct injection into the ducts show dilatation of the main bile duct and of the canal of Wirsung distal to a short stenosis in the head of the pancreas. As a rule the extent of the narrowing of the common bile duct is greater than in this case.

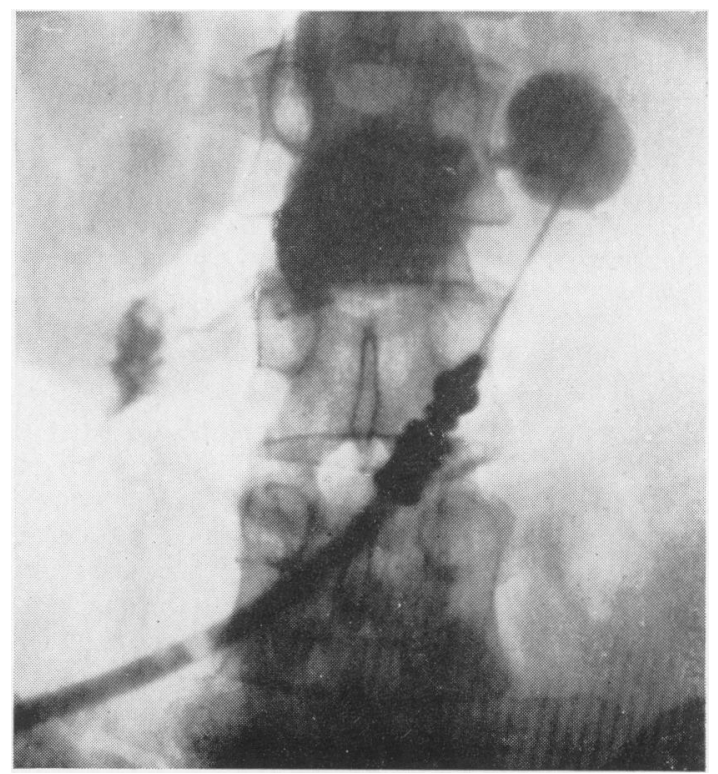

FIG. 9. Calcifying pancreatitis: normal duct of Wirsung. Two intrapancreatic cysts. The duodenum filled at a normal pressure. 


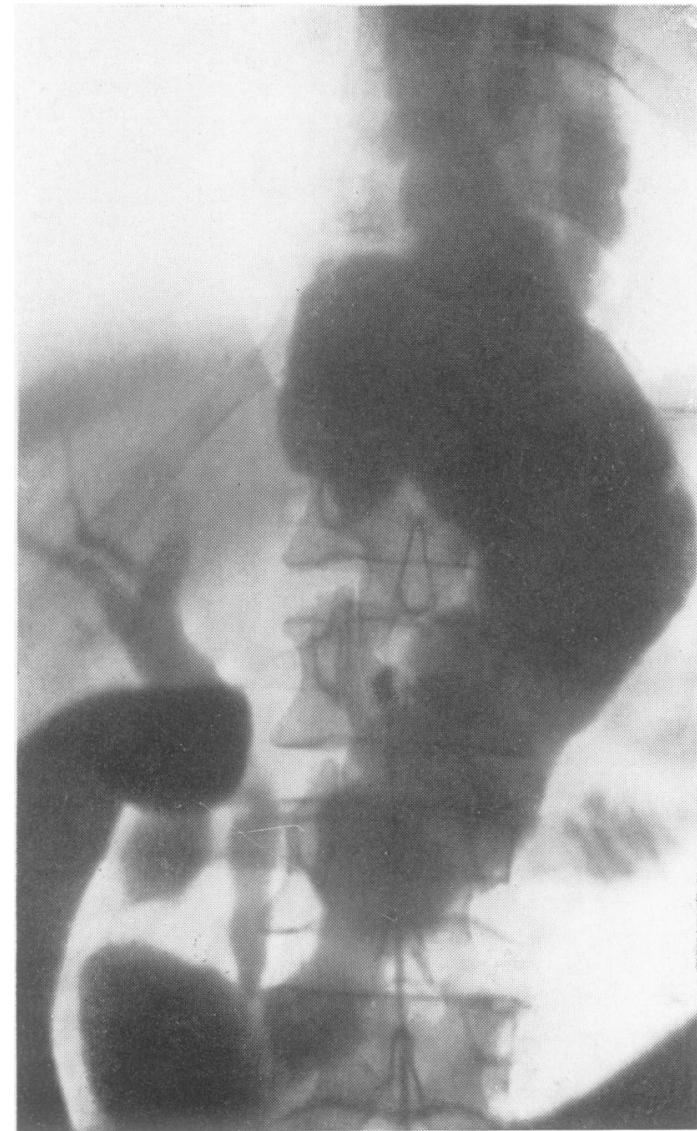

FIG. 10. Calcifying pancreatitis: cholangiography by gall bladder puncture during operation. Direct injection of a voluminous extrapancreatic cyst which traverses the diaphragm to lie in the thorax.

cholangiographies the bile duct was normal but in 61 cases a quite typical appearance existed of retraction of the retropancreatic bile duct leading to a normal patent sphincter of Oddi (Fig. 7). In two cases incomplete stenosis at the upper border of the pancreas was present. In only three cases was bile seen to reflux from the biliary into the pancreatic passages. Further, in one case no reflux was seen on cholangiograms taken early in the operation but it was seen later after the surgeon had removed calculi from the duct of Wirsung.

Splenoportography This was done on five occasions and showed obstruction of the splenic vein in four patients, caused by compression (Fig. 11) in three instances and by thrombosis in one (Fig. 12). Lymphangiography was done in cases showing compression of the retropancreatic lymphatics with retrograde stasis and dilatation of the peripheral

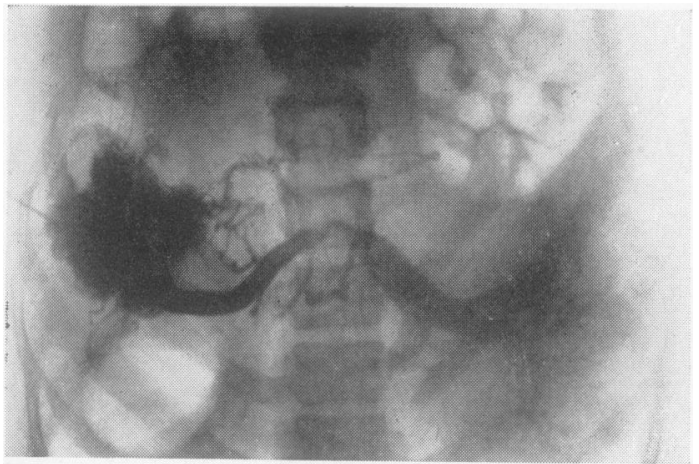

FIG. 11. Calcifying pancreatitis: transparietal splenoportography reveals compression of the splenic vein anterior to the spine.

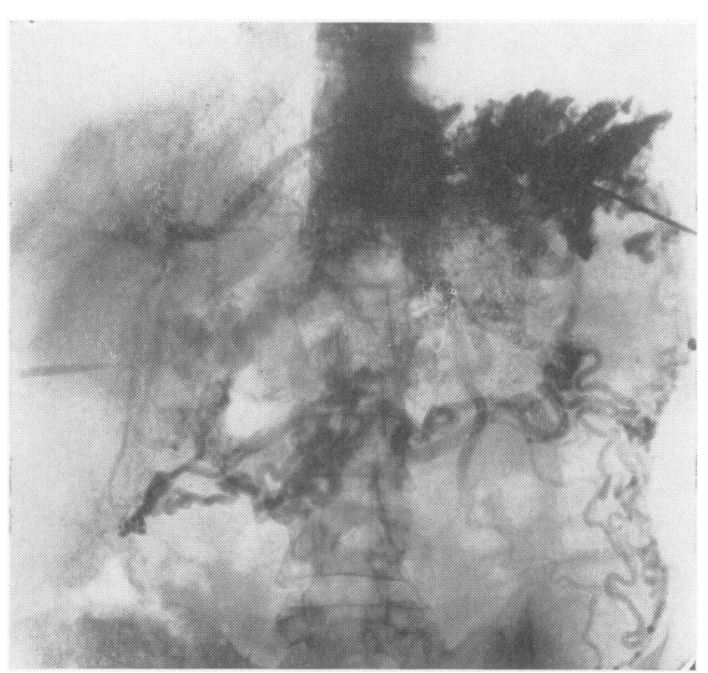

FIG. 12. Calcifying pancreatitis: transparietal splenoportography. Thrombosis of splenic and portal veins with revascularization of the liver by collateral vessels.

lymphatic trunks. Lymphatic obstruction was always incomplete.

CHRONIC PANCREATITIS SECONDARY TO OBSTRUCTION IN THE DUCT OF WIRSUNG In three cases, two men and one woman, the diagnosis of Vaterian stenosis was confirmed by histological examination of a biopsy specimen obtained at operation and on two occasions at necropsy. None of the patients was an alcoholic. In no case was there associated biliary lithiasis.

The symptoms always resembled those of biliary rather than pancreatic disease, painful crises in the epigastrium and in the right hypochondrium lasting for some hours, recurring and accompanied in two cases by rigors with fever as high as $40^{\circ} \mathrm{C}$. and 
followed by recurring icterus. The lesions (Fig. 13a and b) are very similar: an inflammatory fibrosis in two cases, but fibrosis with no inflammation in the other, this being more prominent in the region of the head of the pancreas and surrounding the ducts. In two of the patients there co-existed a cholestatic cirrhosis of the liver, the lesions of the liver being much more intense than those of the pancreas.

One woman presented at the age of 52 years with a severe attack of acute pancreatitis, confirmed at exploratory laparotomy, after which she had repeated attacks of pancreatitis. At a second operation a stone was found in the gall bladder which had escaped recognition at the first operation. The head of the pancreas appeared to be normal but in the region of the isthmus the pancreas was replaced by cartilaginous cicatricial tissue. In the region of this scar the canal of Wirsung was completely obliterated, but in the tail of the pancreas the duct was widely dilated. The scar compressed both the common bile duct and the portal vein. Histologically

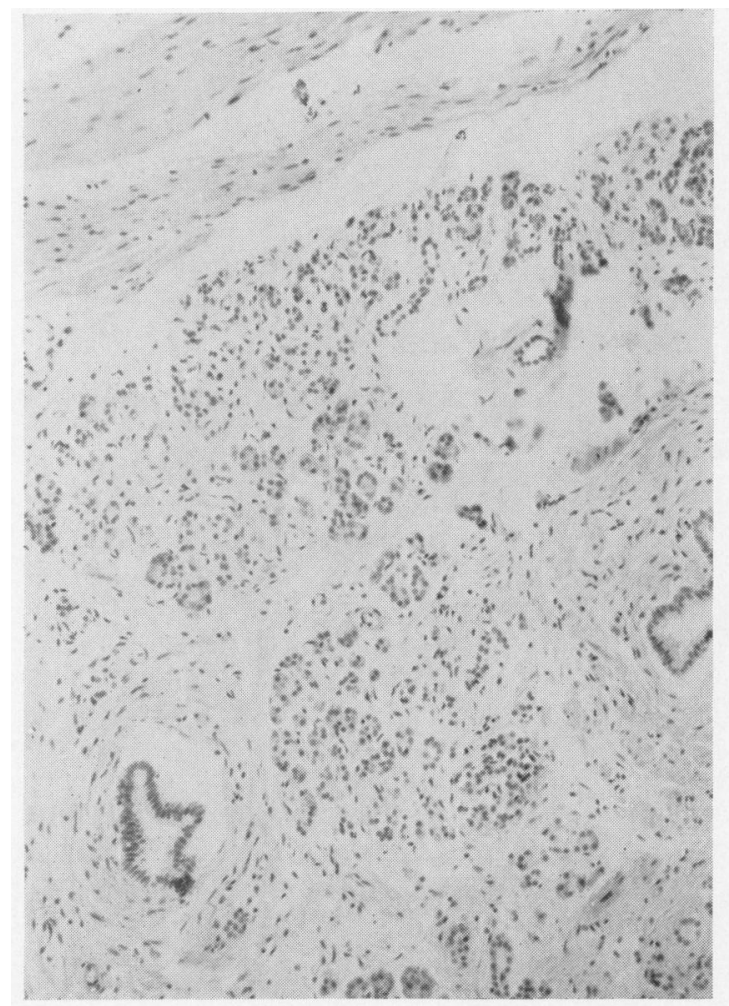

FIG. 13a at the junction of the head and the body of the pancreas there was a ring of sclerosis containing no recognizable acinar tissue which completely surrounded the duct of Wirsung which was lost in this tissue. At the tail of the pancreas the sclerosis remained severe and dense with little inflammation and the exocrine parenchyma was non-existent without any acino-canalicular dilatation. A number of isolated islets of Langerhans remained in sclerotic tissue.

Three patients, one man and two women, had chronic pancreatitis as the sequel to a slowly growing carcinoma. The first two had been operated on several times during the three years that their illness lasted. The successive laparotomies for biliary and pancreatic anastomoses had permitted the taking of repeated pancreatic biopsies which had always shown lesions of benign pancreatitis. At necropsy in two cases diffuse fatty sclerotic lesions, both extra and intralobular, were found, leaving quite large areas of parenchymatous tissue separated by

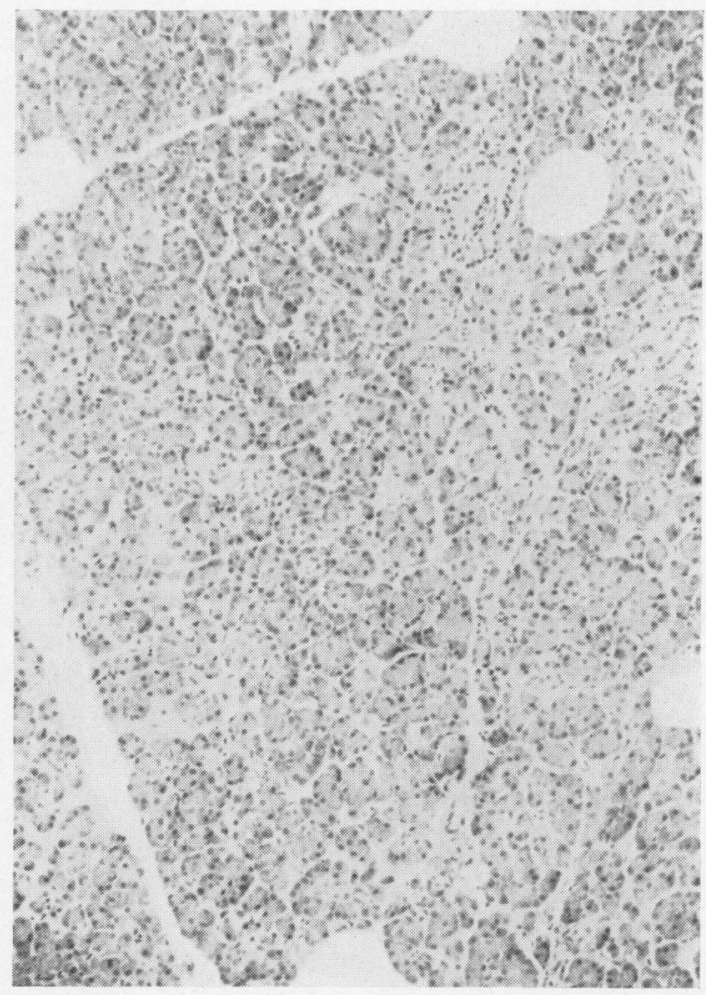

FIG. $13 b$

FIG. 13. Chronic pancreatitis and Vaterian stenosis: (a) section in the region of the duct of Wirsung and of the common bile duct reveals diffuse sclerosis and periductal inflammation; (b) a second section made distally shows that the lesions are not present. 
areas of necrosis. There existed in addition a hyperplastic proliferation of the ducts. In the region of the head of the pancreas the sclero-lipomatosis was most intense, the pancreatic tissue meagre, and there was neoplastic compression of the duct of Wirsung. The third patient presented with cancer of the body of the pancreas obstructing the duct of Wirsung which was dilated. The distal branches contained calcium deposits but none were found proximally in the head or in the region of the tumour.

One of our patients had a quasi-experimental chronic pancreatitis after ligature of the duct of Wirsung in the course of a gastrectomy for ulcer of the second part of the duodenum.

PRIMARY INFLAMMATORY PANCREATITIS Four patients, three women and one man, age of onset $57,59,61$ and 73 years, belong to this group.

One patient had gall stones. None was an alcoholic. There was a progressive development of the disease, without crises, marked by a progressive loss of weight and steatorrhoea. Pain, which was present in only two cases, was quite atypical and less severe than in other types of pancreatitis. One patient presented with obstructive jaundice which did not disappear after biliary drainage. One woman presented during two years with an undulating fever resembling brucellosis which did not respond to antibiotics. In two cases death terminated cachexia over a period of one to three years. Necropsy allowed us to eliminate cancer as a cause. In two other cases, in the course of which surgical intervention allowed us to take multiple biopsies of the pancreas, spontaneous clinical cure took place and was accompanied by the complete disappearance of steatorrhoea.

Histological study was carried out on two cases by biopsy and two cases after necropsy. Microscopy showed marked sclerosis (Fig. 14), not condensed, with scattered areas infiltrated with mononuclear cells and even focal agglomeration of pyknotic polynuclear cells. This sclerosis was diffuse in three cases with no evidence of any parenchymatous structure other than a few canaliculi and endocrine islets. In the fourth case it formed scattered or widely separated foci interspersed with zones of necrosis in which there remained several acinar rests. This is analogous to a acute hepatic necrosis at the stage of connective tissue proliferation.

Sclerolipomatosis was a feature of three cases. The duct of Wirsung was normal in three cases and dilated distal to a stenosis situated in the region of the neck in the fourth. The common bile duct presented an appearance identical to that of the duct of Wirsung. Biochemically there appeared to be marked exocrine pancreatic deficiency with steator-

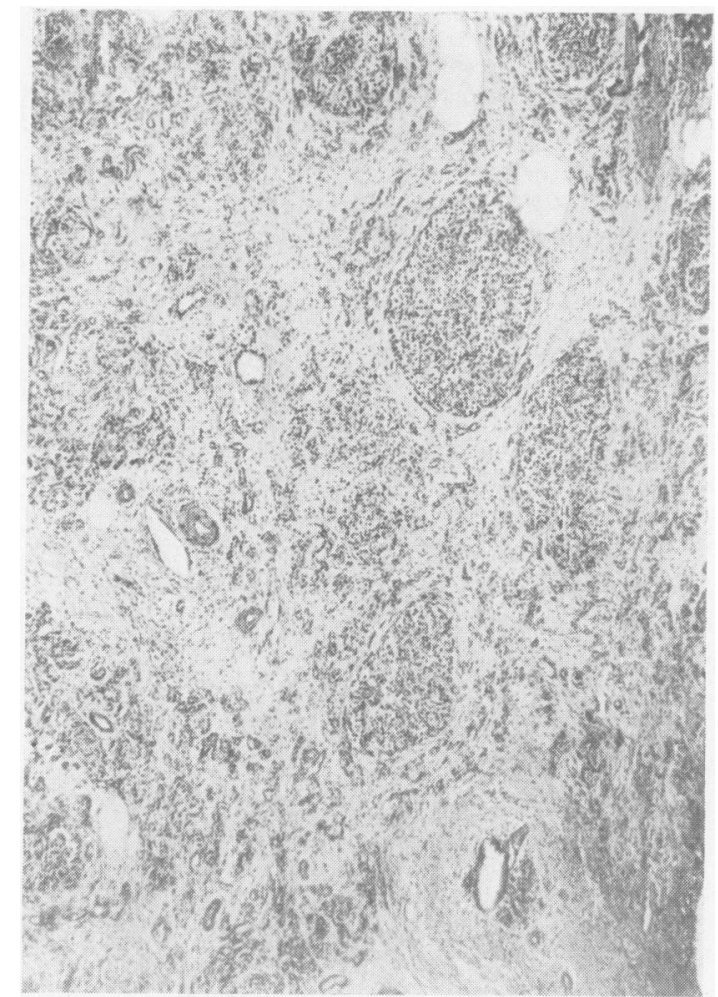

FIG. 14. Primary inflammatory pancreatitis: complete destruction of exocrine pancreas. The islets alone remain in the midst of dense inflammatory sclerotic tissue.

rhoea and a constant increase in the gamma globulin to the level of $40 \%$ and an absence of abnormalities of glucose tolerance. Blood cultures were negative. In two persons immune antibodies against the pancreas were sought but none were found.

CHRONIC PANCREATITIS Three cases were difficult to classify.

Two cases, both in men, are interesting, because they manifested lesions which we think characteristic of calcifying pancreatitis, particularly the multiple features of canalicular dedifferentiation of the acini, the mucous plugs, and the dilated ducts. But these two patients did not present radiological calcification. Both died a short time after surgical intervention on the fifth day and in the second month respectively.

A man of 29 years presented with five recurrences of obstructive jaundice without pain or fever, lasting from 48 hours to eight weeks. In the course of surgical intervention cholangiography showed in the lower part of the common duct, for about $1 \mathrm{~cm}$. proximal to the sphincter of Oddi, a gap $1 \mathrm{~cm}$. long 


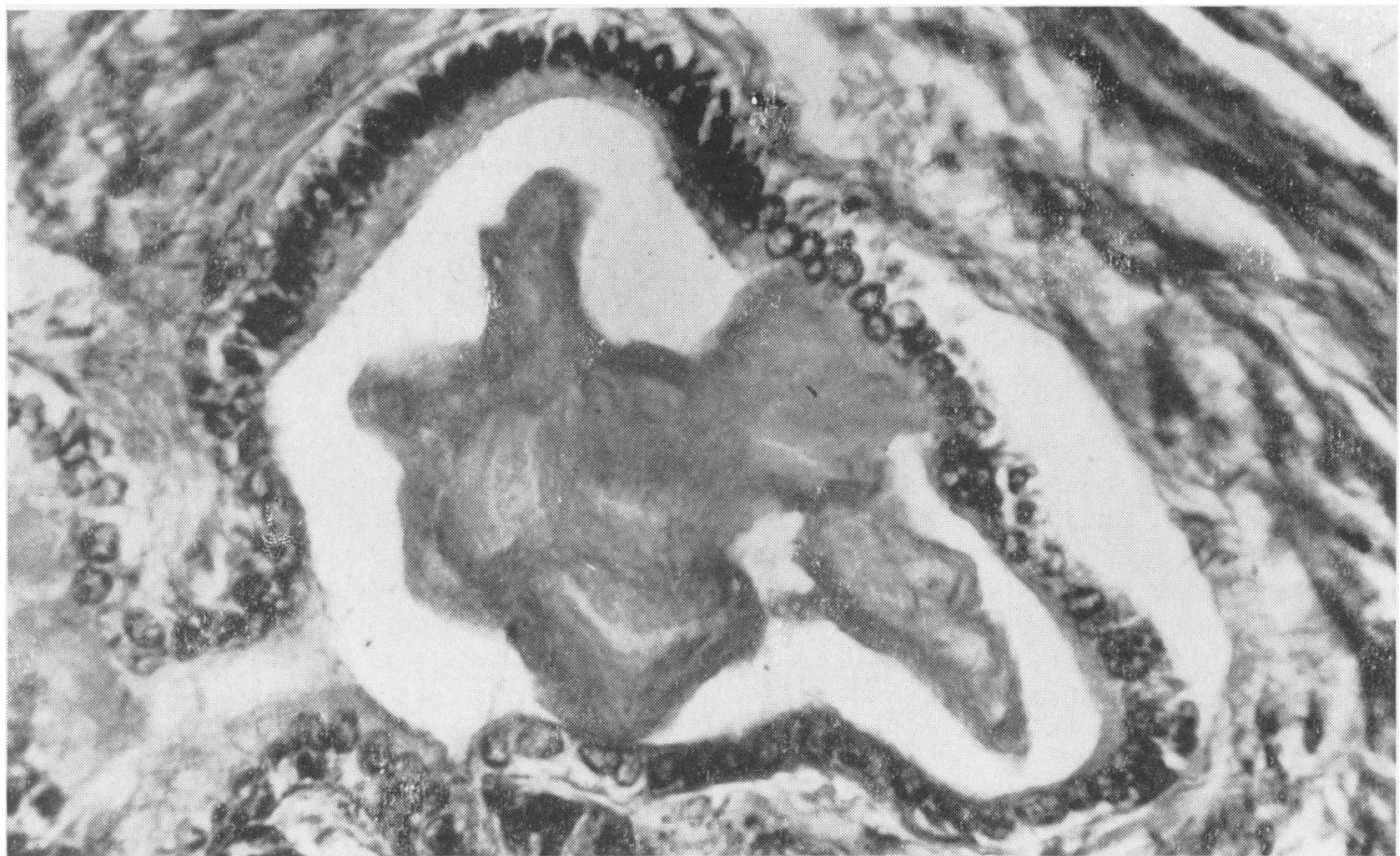

FIG. 15. In this patient, the pancreas is normal with the sole exception of one lobule. In this lobule the smallest ducts contain protein plugs such as are found in calcifying pancreatitis.

reducing the lumen of the bile duct but not completely obstructing it. This led to an erroneous diagnosis of cancer of the common bile duct and a duodeno-pancreatectomy was performed. The specimen showed that the pancreas was normal with the exception of a single pathological lobule situated in contact with the common bile duct which it was deforming. In this region there existed a peri- and intralobular sclerosis, acinar dedifferentiation, and the smallest ducts contained protein plugs such as are found in calcifying pancreatitis (Fig. 15). The duct of Wirsung was normal.

ACUTE PANCREATITIS AND ACUTE RECURRING PANCREATITIS There were 90 cases.

Aetiology The mean age was $51 \cdot 7$ years (range 22 to 73 ; S.D. 12.8). In 54 men mean age was $50 \cdot 9$ years and in 36 women it was 54.7 years. Gall stones were found in 46 cases $(51 \%)$. Amongst these cases with stone there were 22 men of mean age $51 \cdot 3$ years and 24 women of mean age 55.4 years. Gall stones were present therefore in about $60 \%$ of the women with pancreatitis and $40.7 \%$ of the men. The stones were present in the gall bladder in 37 cases and in nine cases in both gall bladder and the common bile duct. In one case a stone was wedged at the ampulla of Vater. Two patients, neither of whom had gall stones, had been treated by corti-
TABLE V

DIETARY INTAKE OF 22 PATIENTS WITH ACUTE PANCREATITIS

\begin{tabular}{|c|c|c|c|}
\hline & $\begin{array}{l}\text { Acute } \\
\text { Pancreatitis } \\
\text { (22 Patients) }\end{array}$ & $\begin{array}{l}22 \text { Controls } \\
\text { (Group A) }\end{array}$ & $\begin{array}{l}22 \text { Controls } \\
\text { (Group B) }\end{array}$ \\
\hline Protein & $\begin{array}{l}93^{1} \\
(52-147)\end{array}$ & $\begin{array}{l}103 \\
(68-135) \\
\text { n.s. } \\
p=0.262\end{array}$ & $\begin{array}{l}100 \\
(50-158) \\
\text { n.s. } \\
\text { p }=0.43\end{array}$ \\
\hline Fat & $\begin{array}{l}99 \\
(60-19)\end{array}$ & $\begin{array}{l}86 \\
(63-120) \\
\text { n.s. } \\
p=0 \cdot 143\end{array}$ & $\begin{array}{l}90 \\
(45-140) \\
\text { n.s. } \\
p=0.416\end{array}$ \\
\hline Carbohydrate & $\begin{array}{l}353 \\
(170-541)\end{array}$ & $\begin{array}{l}416 \\
(220-708) \\
p=0.067\end{array}$ & $\begin{array}{l}465 \\
(270-831) \\
p=0.067\end{array}$ \\
\hline $\begin{array}{l}\text { Calories without } \\
\text { alcohol }\end{array}$ & $\begin{array}{l}2,670 \\
(1,924-3,961)\end{array}$ & $\begin{array}{l}2,860 \\
(1,910-3,928) \\
\mathrm{p}=0 \cdot 584\end{array}$ & $\begin{array}{l}3,090 \\
(1,926-5,000) \\
p=0 \cdot 262\end{array}$ \\
\hline Alcohol & $\begin{array}{l}93 \\
(0-245)\end{array}$ & $\begin{array}{l}57 \\
(0-285) \\
A P>A \\
p=0.002\end{array}$ & $\begin{array}{l}50 \\
(0-221) \\
\mathbf{A P}>\mathbf{B} \\
\mathbf{p}=0.008\end{array}$ \\
\hline
\end{tabular}

${ }^{1}$ The values in italics are the means in grams and calories per day; the values in parenthesis are the range. Significance is calculated by the sign test.

costeroids for respectively three and six months, one for leukaemia, the other for Addison's disease. Acute pancreatitis occurred in a women of 35 years in the eighth month of pregnancy and in another case after normal delivery. There were no gallstones in 
these two cases. In 39 cases $(43 \%)$ no causal factor could be discovered. A pre-existing diabetes was found only twice. Twenty-two patients had a dietetic enquiry (Table V).

Clinical features These are presented in Table VI.

Of the 67 patients who survived, 14 presented with recurring painful episodes of acute relapsing pancreatitis. They comprised six with bile duct stone in whom surgical removal led to a definitive cure and six cases with necrotic cysts difficult to diagnose, the evolution of which appeared to be sufficient to explain the pain. Two patients presented with recurrent pain without our being able to ascertain a cause. Of the 39 patients followed for more than two years, clinical cure was observed in all either spontaneously or after treatment of the cyst or common duct stones. Only one patient who had acute pancreatitis progressed to chronic pancreatitis, in which group she is classified. No patient developed calcification.

\section{TABLE VI}

FREQUENCY OF THE CLINICAL MANIFESTATIONS IN 90 PATIENTS WITH ACUTE PANCREATITIS

\begin{tabular}{lc} 
& $\begin{array}{c}\text { Frequency } \\
(\%)\end{array}$ \\
\hline Pain & 100 \\
Pain referred to back & 54 \\
Vomiting & 67 \\
Paralytic ileus & 58 \\
Dyspnoea & 10 \\
Shock & 44 \\
Transient hypertension & 13 \\
Temperature exceeding $38^{\circ}$ C. & 60 \\
Meteorism & 72 \\
Moderate guarding & 49 \\
Rigidity & 15 \\
Jaundice & 17
\end{tabular}

Pathological anatomy There was oedematous pancreatitis in 18 cases and acute necrotic haemorrhagic pancreatitis in 72 cases. Frank infection of the lesion supervened in 14 cases. Fourteen patients developed a necrotic pseudocyst as a sequel. This was situated in 11 cases in the epigastrium, in one it was situated in the right iliac fossa, and in two cases in the left iliac fossa.

\section{DISCUSSION}

The most important group is that of primary chronic calcifying pancreatitis, which represents almost a fifth of the cases of pancreatic insufficiency not due to cancer. This frequency is in conformity with that which is met in the United States (Comfort et al., 1946; Gambill et al., 1948; Howard and Jordan, 1960) and in South Africa (Marks and Bank, 1963). It is very different from that met in England (Howat,
1965), in Czechoslovakia (Herfort, 1965), in Switzerland (Haemmerli and Schmid, 1965), or in the Argentine (Morel, 1963). On the whole the frequency of calcifying pancreatitis in the western world appears to parallel the consumption of alcohol.

This group of calcifying pancreatitis as we have defined it excludes pancreatic calcification secondary to an obstruction of the duct of Wirsung (one case), juvenile familial pancreatitis, and hyperparathyroidism which we ourselves have not met. The characteristics of the group are the preponderant incidence in men, the onset in middle adult life, and the progressive evolution of the disease often punctuated by painful acute recurring crises. Anatomically a characteristic feature is the irregularity of distribution of the lesions so long as the duct of Wirsung is not involved. The initial lesion as seen on microscopy is perhaps obstruction of the finer pancreatic ducts by a gel which seems to represent the precursor of calcification. Distal to this lesion the ducts and the acini are dilated. Sclerosis is at first localized to the region where the ducts are obstructed, then, as soon as the duct of Wirsung is involved, it diffuses throughout the organ to become a veritable cirrhosis. Thanks to histological verification of these lesions the diagnosis of calcifying pancreatitis has been made early, as long as one to three years before the appearance of radiological calcification, in five of our patients. Thus we consider that the disease presents with characteristic anatomical lesions before the appearance of calcification; that is why we associate with this group observations D.1, D.2, and D.3. In D.3, the focus of chronic pancreatitis was so localized, as small as a grain of wheat, that no clinical symptoms would have ensued had not the common bile duct been compressed.

The connexion of primary calcifying pancreatitis with pseudo-cysts of the pancreas deserves to be emphasized. In a previous report (Sarles, Martin, Camatte, and Sarles, 1963) we have shown that extrapancreatic pseudo-cysts of a solitary character have the same aetiological and pathological features as those seen in calcifying pancreatitis. Meticulous histological study of the wall of these cysts allows us to conjecture that they arise not following an acute necrosis of the pancreas but by distension and a blowing out of foci of localized acino-canalicular dilatation which we have described with eventual rupture into the peripancreatic tissues. Quite different are the necrotic pseudocysts seen as a feature of acute pancreatitis.

The illness does not appear to be due to the scarring of several successive attacks of acute pancreatitis as is the tryptic pancreatitis of Becker 
(1957). In spite of the intensity of the pain which may be present in the first attack, none of these patients has begun the illness by a dramatic abdominal lesion with shock such as would make one think of acute pancreatitis. Calcifying pancreatitis begins, at an average, some 13 years sooner than acute pancreatitis. The mean age of onset of the diseases is respectively 38.4 and 51.7 years. In none of our cases have we found signs of a parathyroid tumour. Neither have we met cases corresponding to the families which Gross, Ulrich, and Maher (1962) and Hardy (1965) described.

Almost all of our patients were alcoholics. The mean consumption of alcohol of those in whom it could be measured by interrogation with accuracy was more than two times greater than that of controls of the same age and the same sex taken at random. Like Howard and Jordan (1960) and Marks and Bank (1963) we think that alcoholism plays a determining role. Our dietectic enquiry shows us that far from consuming less protein than normal controls our patients have eaten significantly more. The consumption of fat was also increased, though the total calorie value of the diet remains very much the same. Though alcohol is an important cause, it is not truly the initial cause of the illness. Indeed neither the clinical evolution nor age nor sex distribution nor pathological anatomy allow us to separate the patients having a low consumption of alcohol from those in whom the consumption is raised. One can therefore put forward a hypothesis that alcohol uncovers a more frequently occurring dormant defect. This hypothesis would accord with the finding by Ludin and Scheidegger (1941) who performed necropsies with minute dissection and radiography of the pancreas and found that pancreatic calcification occurred in $5.5 \%$ of cases, the great majority of which had no clinical symptoms or features. It is possible that protein insufficiency found by Zuidema (1960) and Shaper (1960) plays the same precipitating relationship to pancreatitis in the underdeveloped countries as it does to hepatic disease.

The acino-canalicular dilatations are reminiscent of certain features of mucoviscidosis. This leads us to ask, as do Koch and Bohn (1963), if there does not exist a hereditary basis for the disease. Sweat tests have been positive in 11 of 42 patients. The comparison of 42 patients with 42 controls of the same age and sex has shown us that the excretion of chloride and sodium is significantly higher in our patients than in controls. The sweat test in adults has, however, been criticized so much that too much stress should not be laid on these results. An adrenal insufficiency could not explain these differences. We give these facts without drawing any conclusion about the very complicated problem of adult mucoviscidosis. Another argument in favour of a genetic factor is the finding of calcifying pancreatitis in families. It is not a matter of large families with numerous cases but two cases in the same family, uncle and nephew in our patients, two brothers (Leger, Perrotin, Detrie, Lebel, Meyer, and Lemaigre, 1962), father and daughter (Fitzgerald et al., 1963), mother and daughter (Koch and Bohn, 1963). Geevarghese, Pillai, and Pitchumoni (1963) found in 100 cases of calcifying pancreatitis three families in which two brothers, a father and a son, and a brother and a sister were affected.

The group of chronic pancreatitis secondary to obstruction of the flow of pancreatic juice is much less homogeneous. In spite of the intensity of the lesions of these patients pancreatic calcification has been seen only in one case.

In the pancreatitis of Vaterian stenosis, the lesions are very circumscribed (pericanalicular sclerosis predominating in the region of the head of the pancreas and diminishing peripherally). The pancreatic symptoms are much less marked than the biliary symptoms (Sarles and Guigou, 1951). The interest of this type of pancreatitis is that Vaterian stenosis provides the sole indication for sphincterotomy.

Pancreatitis secondary to cancers of slow development are very difficult to diagnose. As Birnstingl (1959) has emphasized, sometimes a meticulously careful necropsy is necessary to uncover the cancer. The inflammatory and destructive histological lesions and the inexorable progress are very similar to what one sees in the group of inflammatory pancreatitis. In one of our patients at least it was thought that death had occurred more from the pancreatitis than the cancer at the end of three years. A second patient died from a severe post-transfusional hepatitis. Case B.7 is a rarity, in that pancreatic calcification was present in the dilated ducts distal to the cancer.

The group of primary chronic inflammatory pancreatitis possessed certain features in common; an evolution with little pain, significant steatorrhoea, often an age of onset quite elderly, a preponderance of women (three women to one man), and an elevation of the gamma globulins in excess of $40 \%$. It is very difficult to distinguish this group from cancer. In two of our cases the diagnosis was made at necropsy and in two cases by symptomatic and functional cure. In spite of a variable evolution the lesions are very similar; they are marked by the spread throughout the pancreas of a intensely destructive sclerosis of inflammatory character without the irregular localization seen in calcifying 
pancreatitis (group 1). The impossibility of finding an infectious agent or an autoimmune factor, the evolution towards death or complete cure suggests that this group is not homogeneous.

Whereas the three preceding groups of chronic pancreatitis were characterized, as Fitzgerald et al. (1963) have said, by a progressive evolution the group of acute pancreatitis that we have defined is characterized by either a fatal outcome or resolution (Sarles and Camatte, 1963). Howard and Jordan (1960) have noted that alcoholic pancreatitis evolves often in a progressive manner punctuated by recurrences and that pancreatitis associated with gall stones is frequently cured.

The feature of resolution appears to us not to be bound to the presence of biliary stone but to the acute character of pancreatitis, pancreatic oedema, or acute haemorrhagic pancreatitis. Although acute pancreatitis not associated with stone represents about the half of this group, one only of our patients had evolved towards a true chronic pancreatitis. The healing of the pancreatic necrosis had lead to a stenosis of the duct of Wirsung, responsible for the sclerosis distal to it. A similar case has been observed by Leger, Poirier, Dubost, Premont, and Boutelier (1962).

The food intake of patients with acute pancreatitis as assessed by our enquiry does not differ markedly from that of controls of the same age and sex. The intake of alcohol is increased, but two of our patients drank no alcohol and eight were drinking less than $50 \mathrm{~g}$. in a day. Fourteen of our cases of acute pancreatitis could be classified as relapsing; in six the pancreatitis had led to a pseudocyst which in turn was responsible for the recurring painful episodes. Following surgical intervention to extirpate the pseudo-cysts, the patients who survived operation were cured. Eight other patients presented also with relapsing acute pancreatitis. In six patients gall stones in the common bile duct had been overlooked. Surgical intervention to remove these stones leads to complete cure without further relapse. In two we found no apparent cause for the recurring pains but these pains did not continue for longer than one year.

The evolution of relapsing acute pancreatitis towards resolution allows us to separate these cases from true chronic pancreatitis. The profound differences which separate acute from chronic pancreatitis, both clinical and functional, have been correlated with a study of the anatomical lesions. This has confirmed that there does not exist 'all the transitions from haemorrhagic pancreatitis which kills in a few hours to the most progressive lesions of calcifying pancreatitis' but that there are different entities with different clinical features, a different aetiology, and different anatomical features.

This rarity of acute pancreatitis progressing towards chronic pancreatitis deserves to be emphasized.

\section{SUMMARY}

Analysis of three groups of proved pancreatitis showed that of 100 cases of chronic pancreatitis with radiological calcification, 93 were in men, seven in women, and the mean age at onset was 38.4 years (22 to 67). The mean consumption of alcohol was more than twice that of controls but at least one patient was a total abstainer. The consumption of fat and protein was also increased. The mean excretion of $\mathrm{Na}^{+}$and $\mathrm{Cl}^{-}$sweat was significantly high. Several family cases in the important statistics favoured the hypothesis of a more frequently occurring dormant defect revealed by nutritional disorders. The most characteristic anatomical lesions were irregularity of their distribution at the onset of the disease; flattening of the epithelial cells surrounding a dilated lumen; plugs in dilated ducts, ductules, or even acini; sclerosis; frequency of pseudocyst of various sizes; the illness not appearing to be due to the scarring of several successive attacks of acute pancreatitis. The pancreatography done in 51 cases revealed dilatation in 42 , always due to obstruction (stenosis or collection of stones), and cholangiography, the rarity of biliary stones and of bilio-pancreatic reflux but the frequency of a typical narrowing of the recropancreatic bile duct.

Fifteen patients without radiological evidence of calcification operated on with pancreatic biopsy revealing fibrosis and diminution of the exocrine parenchyma. In eight cases the pancreatitis was due to an obstruction of the duct of Wirsung (three Vaterian stenosis, one cicatricial occlusion of the duct after an acute haemorrhagic pancreatitis, three slow growing cancers, one surgical ligature of the duct of Wirsung). None had dilatation of the acini or small ducts. Only one developed pancreatic stones.

Four patients had an intensely destructive sclerosis of inflammatory character without the irregular localization or the acinocanalicular dilatation seen in the calcifying pancreatitis. The clinical course was marked by evolution with little pain, fever, elevation of the gamma globulin. Two patients died and two cases appeared to be cured symptomatically and functionally. No cause was found.

Three cases seemed to represent the initial lesion of a calcifying pancreatitis.

In 90 cases of acute pancreatitis, gall stones were found in 46 cases; 18 had oedematous pancreatitis, 
72 haemorrhagic pancreatitis, and 23 patients died at the first attack. On the 67 who survived, 14 presented with recurring episodes of acute relapsing pancreatitis. Only one patient progressed to chronic pancreatitis due to cicatricial obstruction of the duct of Wirsung. The rarity of proved acute pancreatitis progressing towards chronic pancreatitis deserves to be emphasized.

\section{REFERENCES}

Becker, V. (1957). Sekretionstudien am Pankrease. Thieme, Stuttgart. Birnstingl, M. (1959). A study of pancreatography. Brit. J. Surg., 47, 128-139.

Burton, P., Evans, D. G., Harper, A. A., Howat, H. T., Oleesky, B., Scott, J. E., and Varley, H. (1960). A test of pancreatic function in man based on the analysis of duodenal contents after administration of secretin and pancreozymin. Gut, 1, 111-124.

Comfort, M. W., Gambill, E. E., and Baggenstoss, A. H. (1946). Chronic relapsing pancreatitis; a study of twenty-nine cases without associated disease of the biliary or gastro-intestinal tract. Gastroenterology, 6, 239-285, 376-408.

Fitzgerald, O. and P., Fennelly, J., McMullin, J. P., and Boland, S. J. (1963). A clinical study of chronic pancreatitis. Gut, 4, 193-216.

Gambill, E. E., Comfort, M. W., and Baggenstoss, A. H. (1948). Chronic relapsing pancreatitis: an analysis of 27 cases associated with disease of the biliary tract. Gastroenterology, 11, 1-33.

Geevarghese, P. J., Pillai, V. K., Pitchumoni, C. S. and (1963). The aetiopathogenesis of chronic relapsing pancreatitis. Proc. 2 nd Wld Congr. Gastroent., pp. 153-155. Karger, Basel and New York.

Gross, J. B., Ulrich, J. A., and Maher, F. T. (1962). Further observations on the hereditary form of pancreatitis. In Ciba Foundation Symposium on the Exocrine Pancreas, edited by A. V. S. de Reuck and M. A. Cameron, pp. 278-309. Churchill, London.

Haemmerli, Y., and Schmid, M. (1965). In Symposium of Marseilles, April, 1963, pp. 58-74. (see Symposium of Marseilles).

Hardy, M. (1965). In Symposium of Marseilles, April, 1963, pp. 189216. (see Symposium of Marseilles).

Hennequet, A., Debris, P., and Marie, J. (1958). La test de la sueur par injection intradermique d'un parasympathicomimétique de synthèse, Sem. Hôp. Paris, 34, 883-885.
Herfort, K. (1965). In Symposium of Marseilles, April, 1963, pp. 3545. (see Symposium of Marseilles).

Howat, H. (1965). In Symposium of Marseilles, 1963, pp. 31-34. (see Symposium of Marseilles).

Howard, J. M., and Jordan, G. L. (1960). Surgical Diseases of the Pancreas. Lippincott, Philadelphia.

Koch, W., and Bohn, H. (1963). Vorkommen von Pankreatopathie mit Verkalkung in Familien mit Mucoviscidosis. Proc. 2nd Wld Congr. Gastroent., pp. 147-152. Karger, Basel and New York., Vol. IV.

Lamy, J., Sarles, J. C., and Bricot, R. (1963). A propos du traitment chirurgical des pancréatites chroniques de l'adulte. Ibid., pp. 738-743.

Leger, L., Perrotin, J., Detrie, Ph., Lebel, M., Meyer, J., and Lemaigre, G. (1962). Pancréatites chroniques familiales. A propos de lésions similaires observees chez deux frères. Presse méd., 70, 1257-1260.

_-, Poirier, A., Dubost, C., Premont, M., and Boutelier, P. (1962). La pancréatite chronique étape ultime de la pancréatite aigue. En faveur de l'unicité de la pancréatite. Ibid., 70, 2095-2098.

Ludin, M., and Scheidegger, S. (1941). Uber Pankreaskonkremente (Rontgenologisch-pathologisch-anatomische Untersuchungen) Klin. Wschr., 20, 690-694.

Marks, I. N., and Bank, S. (1963). The aetiology, clinical features and diagnosis of pancreatitis in the south western Cape. S. Afr. med. J., 37, 1039-1053.

Morel, C. J. L. (1963). Pancreatitis Cronical. Lopez, Beunos-Aires.

Sarles, H., and Camatte, R. (1963). Pancréatites Aigues. Masson, Paris.

and Guigou, C. (1951). Pancréatites et papillites chroniques primitives. Sem. Hôp. Paris, 27, 3266-3276.

_- Martin, M. Camatte, R., and Sarles, J. C. (1963). Le démembrement des pancréatites: les pseudokystes des pancréatites aigues et des pancréatites chroniques. Presse méd., 71, 237-240. and Mercadier, M. (1960). Les Pancréatites Chroniques de l'Adulte. L'Expansion Scientifique Francaise, Paris.

_-, Muratore, R., and Sarles, J. C. (1961). Etude anatomique des pancréatites chroniques de l'adulte. Sem. Hôp. Paris, 37, $1507-1522$.

Shaper, A. G. (1960). Chronic pancreatic disease and protein malnutrition. Lancet, 1, 1223-1224.

Symposium of Marseilles, April 1963. (1965). Etiology and pathological anatomy of chronic pancreatitis. Bibl. gastroent. (Basel).

Trémolières, J., Serville, Y., and Jacquot, R. (1956). Manuel Élémentaire d'elimentation Humaine, vol. 3. Pratique de l'Alimentation. Editions Sociales Francaises, Paris

Zuidema, P. J. (1960). Cirrose en calcificatie von de pancreas bij patienten mit wanvoding. T. Gastro-ent., 3, 77-80. 